\title{
Natural and Sun-Induced Aging of Human Skin
}

\author{
Laure Rittié and Gary J. Fisher \\ Department of Dermatology, University of Michigan Medical School, Ann Arbor, Michigan 48109 \\ Correspondence: Irittie@umich.edu; gjfisher@umich.edu
}

With worldwide expansion of the aging population, research on age-related pathologies is receiving growing interest. In this review, we discuss current knowledge regarding the decline of skin structure and function induced by the passage of time (chronological aging) and chronic exposure to solar UV irradiation (photoaging). Nearly every aspect of skin biology is affected by aging. The self-renewing capability of the epidermis, which provides vital barrier function, is diminished with age. Vital thermoregulation function of eccrine sweat glands is also altered with age. The dermal collagenous extracellular matrix, which comprises the bulk of skin and confers strength and resiliency, undergoes gradual fragmentation, which deleteriously impacts skin mechanical properties and dermal cell functions. Aging also affects wound repair, pigmentation, innervation, immunity, vasculature, and subcutaneous fat homeostasis. Altogether, age-related alterations of skin lead to age-related skin fragility and diseases.

\begin{abstract}
kin, like many other organs, undergoes delSeterious changes with the passage of time and associated hormonal and dietary variations. Unlike most other organs, however, skin is also directly affected by exposure to the environment, especially UV irradiation from the sun. Chronic exposure to UV irradiation causes an aged phenotype (photoaging) that is superimposed with aging caused by the passage of time (chronological aging). As a result, areas of the body that are frequently exposed to the sun such as the face, neck, forearms, or back of the hands acquire visible signs of aging more rapidly than other areas of the body.

Skin serves two vital functions. First, skin serves as a barrier; it protects physical, chemical, and bacteriological intrusion in the body, and
\end{abstract}

prevents dehydration by evaporative water loss. Second, skin allows thermoregulation through regulation of skin-hosted vasculature and eccrine sweat glands. In addition to these vital functions, skin mediates the sense of touch and plays a role in immune surveillance, hormone production, and social communication. Each of these functions is affected with aging. In general, alterations of skin structure and function appear earlier and are more pronounced in photoaged than in chronologically aged skin. Evidently, photoaging is a cumulative process and, as such, is more severe in older individuals.

Passage of time and repeated exposure to harmful aspects of the environment alter both the epidermal and dermal compartments of the skin. Clinically, chronologically aged skin ap-

Editors: Anthony E. Oro and Fiona M. Watt

Additional Perspectives on The Skin and Its Diseases available at www.perspectivesinmedicine.org

Copyright (C) 2015 Cold Spring Harbor Laboratory Press; all rights reserved; doi: 10.1101/cshperspect.a015370

Cite this article as Cold Spring Harb Perspect Med 2015;5:a015370 
pears thin, dry, and finely wrinkled. Photoaged skin typically appears leathery, lax, with coarse wrinkles, "broken"-appearing blood vessels (telangiectasia), and uneven pigmentation with brown spots (lentigines). A variant of facial photoaging has been noted in which the skin is relatively smooth with prominent telangiectasia (Brooke et al. 2001). Histologically, both aged and photoaged skin display epidermal differences. Effects of natural aging and photoaging on the dermis are also profound and most obviously involve deleterious alterations to the collagenous extracellular matrix. In this article, we will summarize our current understanding of the features and mechanisms of skin chronological aging and photoaging.

\section{EFFECTS OF AGING ON SKIN BARRIER AND THERMOREGULATION FUNCTIONS}

The epidermis is the outermost layer of the skin. It contains no blood vessels and relies exclusively on the underlying dermis for nutrients. The epidermis is primarily made of keratinocytes organized in a stratified epithelium. Proliferating keratinocytes reside in the basal layer, which lie on a basement membrane at the dermal-epidermal junction. Keratinocyte maturation involves loss of proliferative capacity and, ultimately, differentiation into corneocytes. Differentiation occurs as keratinocytes migrate upward toward the skin surface through the stratum spinosum, stratum granulosum, and stratum corneum. The stratum corneum, the outermost layer of the epidermis, is made of protein-enriched corneocytes embedded in a lipid-rich extracellular matrix (Elias et al. 1977). This "brick and mortar" organized lipid shield provides a waterproof, impermeable barrier that prevents water egress and xenobiotics ingress through the skin (Elias et al. 2010). As a person ages, basal keratinocyte proliferation is reduced, resulting in an overall thinning of the epidermis (Kligman 1979; Montagna and Carlisle 1979; Lavker 1995), and the dermal-epidermal junction appears flattened with shorter epidermal rete pegs and dermal rete ridges (Lavker et al. 1987). These features also occur with photoaging, although to a more variable extent (Lavker 1995; Giangreco et al. 2010). Flattening of the dermal-epidermal junction is thought to reduce the exchange surface between epidermis and dermis, reduce the nutrient flux, and thereby might have a role in reducing keratinocyte proliferation (Lavker et al. 1989). Flattening of the dermal-epidermal junction also reduces epidermal resistance to shearing forces and thereby makes the epidermis more fragile (Lavker et al. 1989). However, thickness of the stratum corneum remains unaltered with advanced age (Lavker et al. 1989; Lavker 1995) and stratum corneum hydration is modestly lowered or unchanged in aged versus young individuals (Man et al. 2009; Luebberding et al. 2013). Accordingly, transepidermal water loss (a measure of stratum corneum integrity) is unaltered with chronological aging (Luebberding et al. 2013). However, surface lipid production decreases significantly with age on some areas of the skin (Man et al. 2009; Luebberding et al. 2013), increasing incidence of xerosis (dry skin), pruritus (itchy skin), and skin irritation in elderly populations (Kligman 1979).

Thermoregulation, the other vital function of the skin, is also affected by the aging process. Humans dissipate excessive heat mostly through the skin via heat transfer to the environment and, most efficiently, via sweat production ( perspiration). Sweat is produced from plasma by eccrine sweat glands (apocrine glands, restricted to armpits and urogenital areas, are not involved in thermoregulation) (Sato and Dobson 1970). Aging decreases heat tolerance and elderly individuals are more susceptible to deadly heat strokes during periods of heat waves. Both the decrease in cutaneous vascular function (Kligman 1979) and reduced sweating rate are involved in reduced sweat function with aging (Inoue and Shibasaki 1996a; Inoue et al. 1999; Hirata et al. 2012). The age-related decreased sweat gland function is believed to develop sequentially from the lower limbs to the upper body and head (Inoue and Shibasaki 1996b). Although morphology of cutaneous nerves is deemed to be little affected by age (Montagna and Carlisle 1979), the sensitivity of sweat glands to cholinergic stimuli may be reduced with age (Inoue et al. 1999). Sweat production is also important for maintaining the acid mantle that 
regulates the growth of skin commensal organisms (Marples 1965; Weller et al. 1996). Consistent with decreased eccrine function, increased age is also associated with defective skin-surface acidity (Choi et al. 2007). The specific influence of photoaging on eccrine sweat gland structure and function remains to be elucidated.

\section{EFFECTS OF AGING ON SKIN REGENERATIVE CAPACITY}

Structural integrity and repair after wounding are critical to skin function. Although aging does not prevent wound healing per se, age-related changes occur in many aspects of wound repair, and clinical observations indicate that wound repair is delayed in aged compared with young individuals (Du Nouy 1916). Wound repair is a continuous process that is comprised of three overlapping phases, that is, inflammatory, proliferative, and remodeling phases. Detailed age-related changes in wound repair have been described in each of these phases (Gerstein et al. 1993; Gosain and DiPietro 2004). Human studies have shown delayed reepithelialization after partial-thickness wounds on the thigh (Holt et al. 1992) and decreased tensile strength after healing of incisional or surgical wounds (Sandblom 1953; Halasz 1968; Mendoza et al. 1970). Similarly, animal studies have shown a $20 \%-$ $60 \%$ delay in wound repair in aged versus young animals (Gosain and DiPietro 2004). However, underlying mechanisms remain unclear. Hair follicle stem cells, which are thought to be the repository of skin regenerative capacity (Lau et al. 2009), persist throughout life (Rittié et al. 2009). Similar findings were reported with epidermal stem cells in mice (Stern and Bickenbach 2007; Giangreco et al. 2008). When placed in culture, human keratinocytes from older skin donors have shorter replicative lifespan than keratinocytes isolated from younger individuals (Barrandon and Green 1987). In human skin, reduced expression of the epidermal stem cells markers melanoma chondroitin sulfate proteoglycan and integrin $\beta 1$ was observed by immunostaining, suggestive of reduced epidermal stem cell number with aging (Giangreco et al. 2008). However, because epidermal stem cells are characterized by relatively higher, as opposed to selective, expression of these markers (Jones and Watt 1993), immunochemistry results remain difficult to interpret (Legg et al. 2003). These findings are yet to be confirmed on isolated cells.

Interestingly, human wounds heal in a unique way, involving epidermal regeneration from eccrine sweat glands (Rittié et al. 2013). Considering the age-related defects of many eccrine sweat gland functions described above, it is conceivable that human eccrine sweat gland regenerative capacity is also altered with aging. This possibility has yet to be investigated.

\section{EFFECTS OF AGING ON SKIN PIGMENTATION, INNERVATION, IMMUNITY, VASCULATURE, AND ADIPOSE}

\section{Aging of Skin Pigmentary System}

Melanin is a group of natural pigments that add color to hair and skin. Melanin is produced by melanocytes that are confined in the basal layer of the human epidermis and the bulb of hair follicles. Melanin pigments are photoprotective (Kollias et al. 1991; Meredith and Sarna 2006) and their production is induced during tanning by UV irradiation (Sklar et al. 2013). In young adult epidermis, melanocytes are distributed relatively evenly on the body at a density of $\sim 1500 / \mathrm{mm}^{2}$ (slightly higher on the head) (Snell and Bischitz 1963; Szabo 1967). Aging is associated with a $10 \%-20 \%$ reduction of melaninproducing melanocytes per decade (Snell and Bischitz 1963; Szabo 1967; Gilchrest et al. 1979; Ortonne 1990), although it is not clear whether this is caused by a net loss of melanocytes, a decrease in their activity, or both. As a result, skin pigmentation and reactive tanning after exposure to UV irradiation is reduced with age in sun-protected areas (Hawk 1990; Ortonne 1990; Shlivko et al. 2013).

In chronically sun-exposed areas, pigmentation becomes uneven with age, and mottled pigmentation is a hallmark of photoaged skin (Lavker 1995; Chung 2003). The most common pigmented lesions in photoaged skin include actinic lengitines ("age spots"), ephelides (freckles), and pigmented solar and seborrhoeic 
keratosis (Ortonne 1990). Increased local pigmentation in photoaging is mostly a result of increased number of dopa-positive melanocytes in the basal epidermal layer (Hodgson 1963; Gilchrest et al. 1979; Ortonne 1990).

\section{Aging of Skin Innervation}

Skin connects to the central nervous system through dense innervation. Skin innervation is traditionally described according to the function it mediates, such as providing the senses of touch, itch, or pain (afferent sensory innervation), as opposed to glandular activity or smooth muscle contraction (efferent autonomic innervation) (Montagna 1977; Fraiture et al. 1998; Reinisch and Tschachler 2012). Aging is associated with an overall decreased sensory perception that correlates with reduced number of nerve fiber endings in epidermis and dermis (Grassi et al. 2003; Panoutsopoulou et al. 2009; Fromy et al. 2010; Namer 2010). On the other hand, a few studies have shown that photoaged skin is characterized by increased sensory nerves (Toyoda et al. 2005) and increased number of epidermal nerve fibers that correlates with the intensity of photoaging (Toyoda et al. 1996) compared with sun protected skin. The functional consequences of these changes in photoaged skin remain hypothetical (Legat and Wolf 2006, 2009).

\section{Aging of Skin Immunity}

Skin's natural barrier is aided by a powerful intrinsic immune system to help protect against infection. Antigen-presenting cells, which traffic throughout the skin, include macrophages, B cells, dendritic cells, and Langerhans cells (the latter being the major antigen-presenting cell in the epidermis). Recent reviews have covered, in detail, age-associated changes in the skin immune systems (Ongrádi et al. 2009; Shaw et al. 2010; Mahbub et al. 2011; Vukmanovic-Stejic et al. 2011). In general, aging is associated with deregulation of the immune response, often referred to as "immunosenescence," which translates to increased susceptibility to infections, increased malignancies, and reduced effectiveness of vaccination. Typically, the number of cutaneous antigen-presenting cells is similar between young and aged subjects, but migration to lymph nodes, phagocytosis, and capacity to stimulate $\mathrm{T}$ cells is reduced in elderly versus young individuals (Takahashi et al. 1985; Bhushan et al. 2004; Agrawal et al. 2007; Ongrádi et al. 2009; Shaw et al. 2010; Mahbub et al. 2011; Vukmanovic-Stejic et al. 2011). Although acute UV irradiation alters immune response in human skin (Baadsgaard et al. 1989; Bennett et al. 2008), the permanent effects of chronic UV exposure on immunity in photoaged skin remain unclear.

\section{Aging of Skin Vasculature}

Skin vasculature is made of a network of blood and lymphatic vessels that resides in the dermis. Skin vasculature allows temperature control and diffusion of nutrient-rich plasma and immune cells. While blood vessels serve as supply lines, lymphatic vessels ensure recycling through back transport to the venous circulation (Armulik et al. 2005; Cueni and Detmar 2006). Blood vessels are formed on interaction between endothelial cells, mural cells (pericytes and vascular smooth muscle cells), and the surrounding extracellular matrix (Armulik et al. 2005; Betsholtz et al. 2005). Aging and photoaging of the skin are associated with reduced number of blood vessels, especially in the upper dermis (Kligman 1979; Braverman and Fonferko 1982; Kelly et al. 1995; Chung et al. 2002). Structural changes in vessel properties also include reduced number of pericyte-covered blood vessels in aged skin (Betsholtz et al. 2005; Helmbold et al. 2006). In addition, endothelial cell flattening and dilation of the remaining vessels are typical of photoaged skin (Kligman 1979). Disruption of blood vessels' normal architecture leads to vascular hyperpermeability and, thus, dysfunction (Armulik et al. 2005; Betsholtz et al. 2005). For instance, maximum cutaneous blood flow, a measure of skin endothelial function in response to heating, is reduced linearly with age (Martin et al. 1995). Similarly, reduced density of lymphatic vessels has been observed in photoaged human skin (Kajiya et al. 2007). Taken to- 
gether, changes in vasculature alter multiple aspects of cutaneous physiology as diverse as increased tendency to bruising, reduced nutrient supply, and altered immune cell trafficking.

\section{Aging of Skin Adipose}

Although traditionally described as part of the skin, the subcutaneous adipose layer is usually studied in relation to nutrition and endocrinology, separately from other skin compartments. Subcutaneous "white" fat represents 85\%-90\% of the total body fat in women, regardless of body mass index (the remaining being visceral or "brown" fat) (Ross et al. 1993; Thomas et al. 1998). The ratio of subcutaneous:visceral fat is lower in male subjects (Ross et al. 1992, 1993). The relative amount of subcutaneous fat varies greatly throughout the body, with the abdomen containing up to four times more subcutaneous fat than the lower legs or the head (Ross et al. 1992, 1993). Interestingly, subcutaneous fat is not organized as a continuous layer, but rather highly partitioned in distinct, independent compartments separated with septal barriers, at least on the face (Rohrich and Pessa 2007, 2008). Aging causes a redistribution of fat that results in reduced subcutaneous:visceral fat ratio (Chumlea and Baumgartner 1989; Hughes et al. 2004). On sun-exposed areas such as the face, aging also causes a redistribution of fat between subcutaneous facial compartments, which is an important part of perceived facial aging (Rohrich and Pessa 2007, 2008). These morphological changes are associated with physiological alteration of adipocyte metabolism and adipokine synthesis (Guo et al. 2007; Kim et al. 2011; Sepe et al. 2011; Gulcelik et al. 2013). Overall, the subcutaneous:visceral fat ratio in aged individuals is a stronger determinant of insulin resistance than amount of visceral fat alone (Gavi et al. 2007; Frederiksen et al. 2009).

\section{EFFECTS OF AGING ON SKIN DERMAL STRUCTURE}

The dermis is the largest portion of the skin and supports the skin vasculature that vehicles oxy- gen, nutrients, immune cells, and the skin appendages. The bulk of the dermis is composed of collagenous extracellular matrix, which confers mechanical strength, resiliency, and elasticity to the skin. These functions are deleteriously altered in both chronologically aged and photoaged skin, albeit to a larger degree in chronically sun-exposed skin. Solar elastosis, that is, accumulation of amorphous elastin-containing material in the upper dermis, is a hallmark of human photoaging and ultimately results in lack of resilience (Braverman and Fonferko 1982; Lavker 1995). Although solar elastosis is not observed in chronologically aged skin, the elastin network is also altered with age in sun-protected skin; while elastic fibers are thin and single stranded in young skin, they appear progressively beaded in older skin with disappearance of terminal fibrils that extend into the epidermis (Braverman and Fonferko 1982; Montagna and Carlisle 1991; Lavker 1995). The protein constituents of elastin fibers are thought to be produced throughout life, although their assembly into intact fibers appears to decline with natural aging (Fig. 1) (Braverman and Fonferko 1982).

Alterations of the organization and structure of type I collagen, the most abundant structural protein in skin, is a hallmark of both chronologically aged and photoaged human skin (Fig. 1). Electron microscopy studies have shown accumulation of degraded collagen fibers over time (Varani et al. 2001, 2006), and biochemical studies have shown that decreased collagen production correlates with severity of photodamage (Talwar et al. 1995) and age of an individual (Uitto 1986; Varani et al. 2000). Progressive fragmentation of the dermal collagenous extracellular matrix has important consequences: it decreases the overall strength of the skin, favors wrinkle formation, and creates a microenvironment that facilitates tumor formation and progression.

\section{Acute UV Irradiation Triggers Transient Collagen Fibril Degradation}

During the past two decades, we have greatly enhanced our understanding of the mecha- 


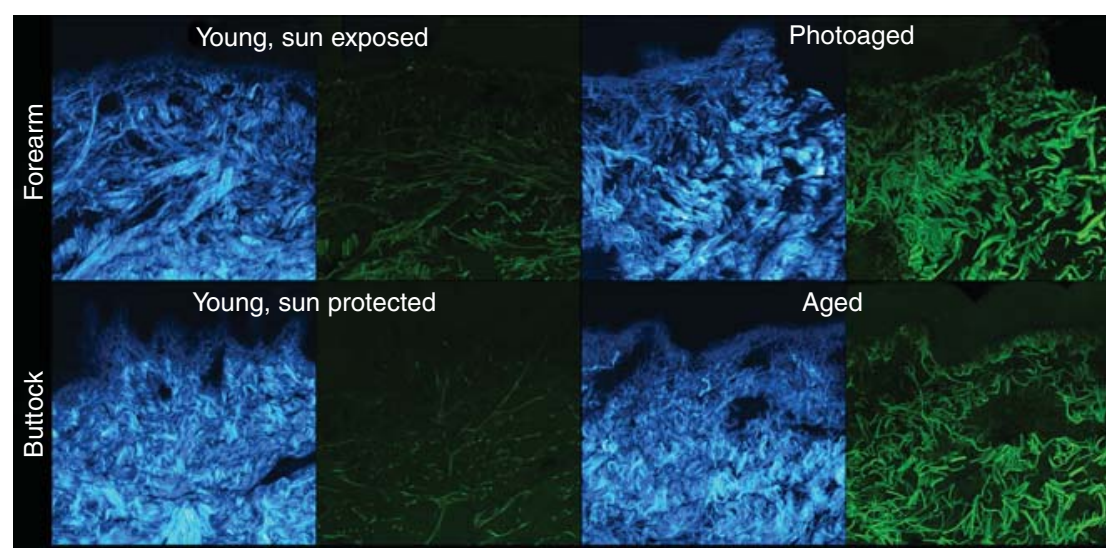

Figure 1. Morphological alterations of collagen and elastin fibers in aged human skin. Collagen second harmonic generation (SHG) (blue, total SHG signal, backward + forward, $\lambda_{\mathrm{exc}}=820 \mathrm{~nm}$ ) and elastin autofluorescence (green, $\lambda_{\mathrm{det}}=500-550 \mathrm{~nm}$ ) of sun-exposed forearm skin samples from individuals aged 25 (top left) and 54 (top right) years, and sun-protected buttocks skin samples from individuals aged 25 (lower left) and 83 (lower right) years. Shown are maximum projections (15- $\mu$ m thickness). SHG imaging highlights abundant collagen fibers in young skin (top and bottom left), and relatively reduced mature collagen content and increased fragmentation in photoaged (top right) and aged skin (bottom right). In addition, photoaging and chronological aging are characterized by the disappearance of small elastin fibers in the upper dermis. Photoaging is characterized by accumulation of elastotic material composed of aggregated elastin fibers (top right). (Human study guidelines approved by the University of Michigan Institutional Review Board.)

nisms by which repeated skin exposure to solar irradiation over decades leads to sustained structural and functional deficits in the dermis. Oxidative stress plays a central role in both aging-associated and UV irradiation-initiated dermal extracellular matrix alterations. On irradiating the skin surface, UV light energy is readily absorbed by endogenous cellular chromophores such as $\mathrm{NADH}^{-} / \mathrm{NADPH}$, tryptophan, riboflavin, or trans-urocanic acid (Hanson and Simon 1998). Chromophore excitation, which occurs in the presence of molecular oxygen, produces an array of oxidation products and radical oxygen species (ROS), including the highly reactive hydroxyl radical $\mathrm{HO}^{\circ}$ (Brenneisen et al. 1998). Although toxic at high concentration, ROS mediate a variety of normal cellular responses at low concentration, such as activation of receptor tyrosine kinases (RTKs) and downstream signaling pathways (Herrlich and Bohmer 2000). ROS produced upon UV irradiation, likewise, activate these RTKs and their associated downstream signaling pathways, bypassing the normal initiation process of binding cognate ligands. Specifically, ROS reversibly reacts with highly conserved cysteine in the catalytic site and thereby inhibits enzymatic activity of receptor protein tyrosine phosphatases (RPTPs) (Knebel et al. 1996; Denu and Tanner 1998; Xu et al. 2002; Meng and Zhang 2013). These RPTPs directly dephosphorylate RTKs and thereby maintain RTKs in low-activation state levels (Fig. 2) (Tonks 2006). Thus, RPTP inhibition is functionally similar to RTK activation. In human keratinocytes, RPTP-к specifically regulates epidermal growth factor receptor (EGFR) tyrosine phosphorylation (Xu et al. 2005) and mediates UV irradiation-activation of EGFR (Xu et al. 2006). Other protein tyrosine phosphatases are also likely to be affected because UV irradiation activates many other RTKs, including cytokine and growth factor cell surface receptors such as tumor necrosis factor- $\alpha$ receptor, platelet activating factor receptor, insulin receptor, interleukin-1 receptor, CD95 (Fas-Ligand receptor), insulin receptor, and platelet-derived growth factor receptor (Herrlich and Bohmer 2000; Rittié and Fisher 2002). The pleiotropic response induced by UV irradiation in skin derives in large part from the 

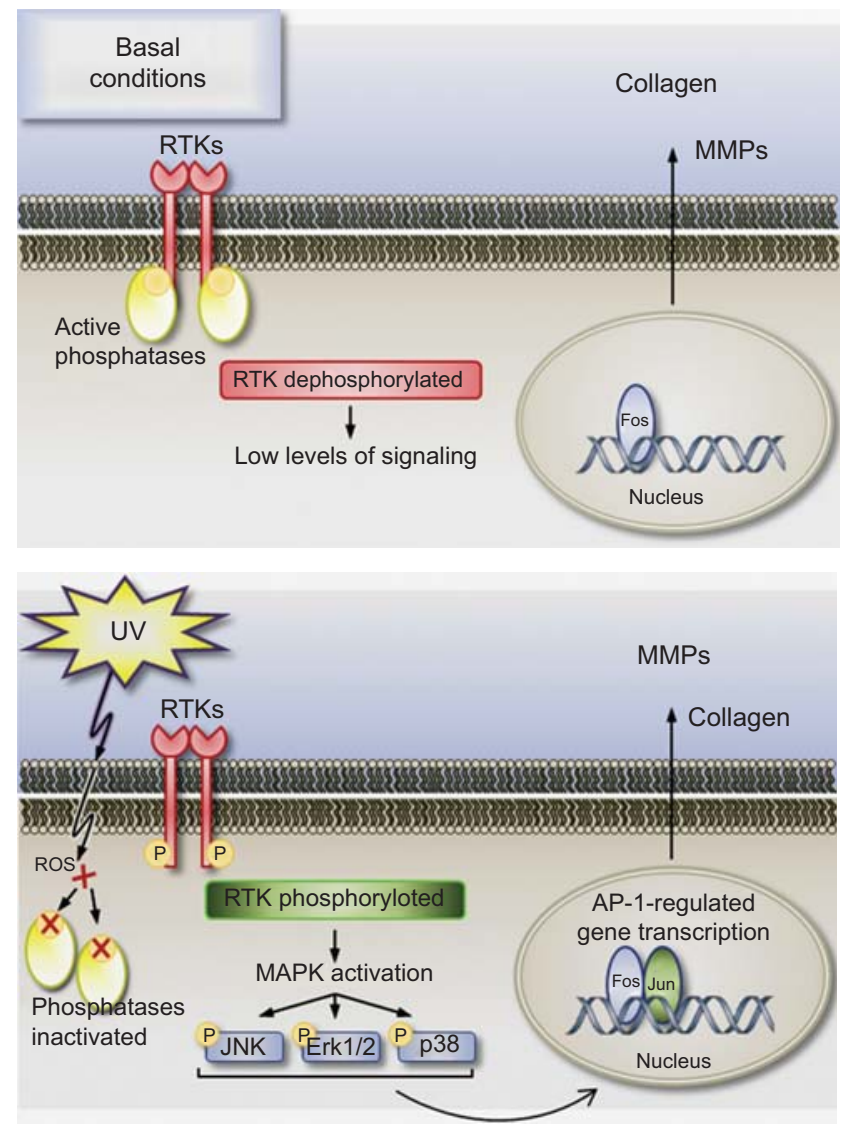

Figure 2. ROS-mediated activation of RTKs signaling cascades by UV irradiation. (Upper panel) In absence of UV irradiation (basal conditions), RTKs and downstream signaling in skin cells are maintained in a low state of activation by protein tyrosine phosphatase activities that dynamically dephosphorylate RTKs. These conditions favor normal collagen synthesis and low production of matrix metalloproteinases (MMPs). (Lower panel) Absorption of UV irradiation energy by skin cell components, in the presence of molecular oxygen, generates reactive oxygen species (ROS) that react with cysteine in the catalytic site of protein tyrosine phosphatases. Inhibition of protein tyrosine phosphatases by reaction with ROS increases net RTK phosphorylation levels and triggers downstream signaling cascades that include mitogen-activated protein kinase (MAPK) phosphorylation and activation of activator protein-1 (AP-1) transcription factor. Activated AP-1 represses collagen production and increases MMP gene transcription. As a result, UV irradiation induces transient collagen deficit.

ability of UV light to simultaneously activate multiple RTKs (Rosette and Karin 1996).

The downstream signaling that follows UV irradiation-mediated RTK activation is similar to that triggered by ligand-binding and has been reviewed in detail elsewhere (Rittié and Fisher 2002). Briefly, downstream signaling consists of recruitment of adaptor proteins and activation of the three families of MAPKs: extracellular signal-regulated kinase, p38, and c-Jun amino-terminal kinase. In human skin, UV irradiation activates MAPKs in the epidermis and upper dermis (Fisher et al. 2002). Activated MAPKs, in turn, phosphorylate the transcription factor c-Jun. c-Jun activation occurs within 30-60 min following UV irradiation of skin in vivo and lasts $24 \mathrm{~h}$ (Fisher and Voorhees 1998). Activated c-Jun enters the nucleus and partners with constitutively expressed c-Fos to assemble the activated AP-1 transcription factor 
complex. AP-1 has a profound influence on collagen homeostasis because it not only stimulates transcription of several collagen- degrading enzymes including MMP-1, -3 , and -9 , but also reduces production of procollagens (soluble precursors to collagens) by inhibiting transcription of genes encoding procollagens I and III.

Other mechanisms are implicated in mediating altered regulation of extracellular matrix protein-encoding genes by UV irradiation. Among them, deregulation of transforming growth factor $\beta$ (TGF- $\beta$ ) pathway is of particular interest, mostly because TGF- $\beta$ is a major profibrotic cytokine in mesenchymal cells (Massagué 2012). In human skin fibroblasts, TGF- $\beta$ is an important regulator of collagen homeostasis by stimulating procollagens I and III and reducing MMP-1 transcription. UV irradiation modulates TGF- $\beta$ pathway at several levels; it decreases type II TGF- $\beta$ receptor within $4 \mathrm{~h}$ in human skin in vivo (Quan et al. 2004), stimulates the intracellular inhibitor of TGF- $\beta$ signaling Smad-7 (Quan et al. 2005), and reduces levels of connective tissue growth factor (CCN2), an essential mediator of TGF- $\beta$ effects on collagen synthesis (Duncan et al. 1999; Quan et al. 2002).

Taken together, UV irradiation causes a collagen deficit by shifting homeostasis from production/deposition to degradation (Fig. 2). Because melanin pigments are photoprotective (Kollias et al. 1991), the biological effects of UV irradiation are more pronounced in individuals with light versus dark skin (Fisher et al. 2002; Wang et al. 2008). In lightly pigmented human skin in vivo, transcripts encoding MMP-1, -3 , and -9 are induced within $8 \mathrm{~h}$ after UV irradiation (Fisher et al. 1996) and enzyme activities are observed $24 \mathrm{~h}$ postirradiation in human skin in vivo (Fisher and Voorhees 1998). Similarly, UV irradiation reduces collagen production; type I collagen transcript and protein levels are decreased within $8 \mathrm{~h}$ following UV irradiation in human skin in vivo, and remain diminished in the upper dermis $24 \mathrm{~h}$ after UVexposure (Fisher et al. 2000). These responses to acute UV irradiation are transient; however, MMP and collagen transcripts normalize to baseline levels by $96 \mathrm{~h}$ postirradiation in human skin (Fisher et al. 1996, 2000, 2002).

\section{Accumulation of Fragmented Dermal Collagenous Extracellular Matrix Sustains Collagen Decline in Aged Human Skin}

The transiently increased degradation and decreased production of collagen fibrils that occur in response to a single exposure of skin to UV irradiation provides insight into the mechanisms that promote sustained collagen deficit (hypocollagenesis), which characterizes chronologically aged and photoaged human skin. When compared in culture, subject-matched dermal fibroblasts isolated from sun-exposed and -protected human skin produce similar amounts of procollagen I (Varani et al. 2001). This observation suggests that photoaging-induced hypocollagenesis is not related to genetic or intrinsic alterations of dermal cells. Likewise, when compared in culture, isolated fibroblasts harbor modest differences in their metabolism and collagen production (Schneider 1979; Varani et al. 2006), differences that may be specific to the fibroblasts residing in the topmost $10 \%$ portion of the dermis (Mine et al. 2008). In any case, the sustained decrease of collagen production in chronologically aged skin measured in vivo appears much more robust than that measured in cultured fibroblasts (Varani et al. 2006). Taken together, these observations support the concept that the dermal microenvironment imposes altered fibroblast functions in chronologically aged and photoaged human skin. Evidence indicates that accumulation of fragmented dermal extracellular matrix is a key factor that mediates many of the characteristic features of aged human skin (see Fig. 3 and below).

As detailed earlier, acute UV irradiation induces ROS in human skin. Elevation of ROS levels is also considered a major driving force for natural aging (Harman 1992; Fisher et al. 2009). Transient increase in ROS levels in skin cells, via the mechanisms described above, leads to up-regulation of MMPs, resulting in collagen degradation. Conceivably, because of cross-linking that confers general resistance to further degradation of type I collagen fibril fragments, col- 

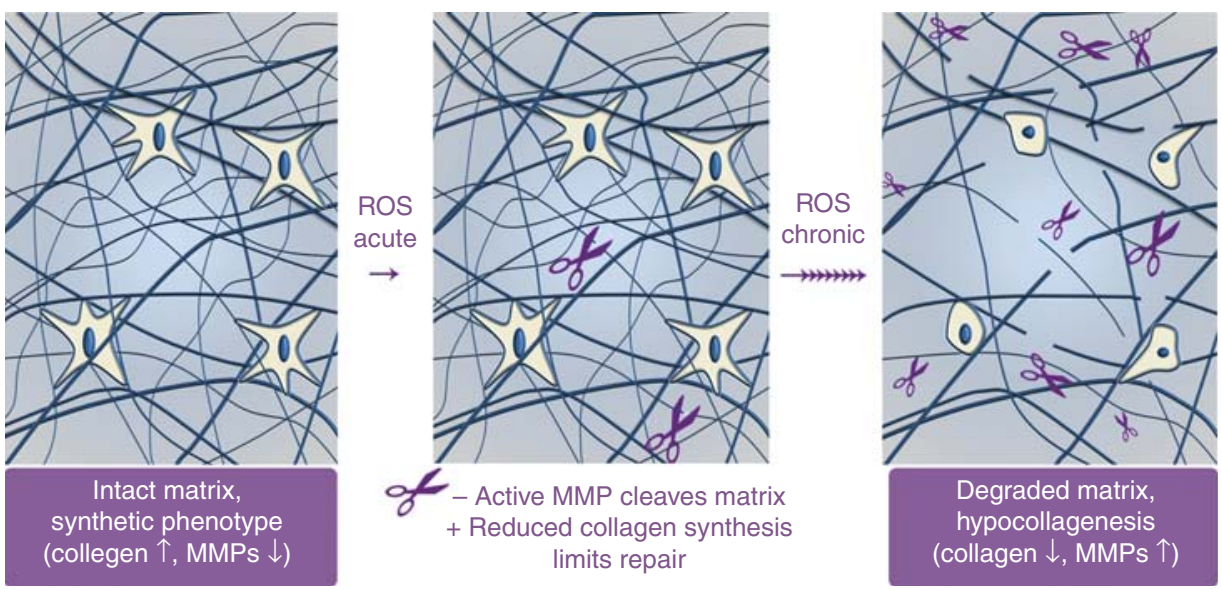

Figure 3. Accumulation of fragmented collagen in the dermal extracellular matrix leads to sustained reduction of collagen production in chronologically aged and photoaged human skin. (Left panel) In young skin, intact collagen within the dermal extracellular matrix provides attachment sites and mechanical resistance for fibroblasts. Fibroblasts are able to stretch and, under relatively high mechanical tension, show normal collagen homeostasis (collagen production is high, MMP production is low). (Middle panel) On exposure to UV irradiation (photoaging) or oxidative stress (chronological aging), elevated ROS activate signaling cascades that promote reduced collagen synthesis and increased MMP production. Active MMPs cleave the collagenous extracellular matrix, whereas reduced procollagen production limits repair. (Right panel) Accumulation of collagen fragments, which occurs with chronic UV exposure and the passage of time, impairs the mechanical and functional properties of the dermal extracellular matrix. Fibroblasts respond to this degraded dermal extracellular microenvironment by up-regulating MMP expression and down-regulating collagen production, thereby creating a self-sustaining phenotype that promotes skin fragility and age-related diseases.

lagen fibril remnants appear to remain bound within the dermal extracellular matrix. In addition, collagen degradation is accompanied by reduced collagenesis, which likely impedes replacement. Over time, fragmented collagen fibril remnants accumulate and become readily observable in photoaged (Varani et al. 2001, 2002) and aged (Fisher et al. 2002; Varani et al. 2006) human skin dermis.

Histologically, fibroblasts in chronologically aged and photoaged human skin are surrounded by fragmented collagen matrix. These fibroblasts appear to be collapsed, with dramatically reduced cell surface area and fewer contact points with surrounding fragmented collagen fibrils (Varani et al. 2006). Like many other cell types, dermal fibroblasts sense the mechanical load of their environment. Mechanical forces are readily transferred from the extracellular matrix to the cell's intracellular scaffolding (cytoskeleton), a phenomenon known as mechanotransduction (Chen 2008). The level of me- chanical tension within a cell that is bound to its extracellular matrix is determined by at least three factors: (1) the traction forces generated by the cell via its cytoskeleton, (2) the intrinsic resistance of the extracellular matrix, and (3) any externally applied forces to the extracellular matrix transmitted to the cell (Chen 2008). In chronologically aged and photoaged skin, accumulation of fragmented collagen decreases the mechanical resistance of the collagenous extracellular matrix and thereby decreases the mechanical forces within resident fibroblasts. This phenomenon is critical because mechanical forces that control cell shape are intimately coupled, although as yet not fully understood mechanisms, to fibroblast functions. Human dermal fibroblasts respond to low mechanical force by increasing their levels of ROS, reducing collagen production and increasing expression of MMPs (Mauch et al. 1988; Delvoye et al. 1991; Eckes et al. 2006; Fisher et al. 2009). Thus, collagen fragmentation fuels a self-perpetuating cycle of 
oxidative stress, reduced collagen synthesis, and increased collagen fragmentation in chronologically aged and photoaged human skin (Fig. 3).

\section{Restoration of Mechanical Tension Restores Extracellular Matrix Production in Aged and Photoaged Dermis}

Based on the above information, it becomes apparent that the structural and mechanical properties of the dermal extracellular matrix are key determinants of age-dependent decline of fibroblast function. Thus, in theory, increasing structural support of the dermal extracellular matrix might be a potential strategy for restoring fibroblast synthetic capacities in chronologically aged and photoaged human skin. Indeed, in vitro studies show that fibroblasts in a mechanically stiffer environment produce more collagen and less MMPs than fibroblasts cultured in a more pliable collagen matrix (Mauch et al. 1988; Rittié et al. 1999; Eckes et al. 2006). More recently, it has been shown that local increase in mechanical forces within the dermis can indeed effectively reprogram fibroblasts to up-regulate collagen production in human skin in vivo (Wang et al. 2007; Quan et al. 2013). Injection of cross-linked hyaluronic acid, a dermal filler commonly used in cosmetic dermatology, was used to enhance the structural support of the dermal extracellular matrix in chronologically aged or photoaged skin. Hyaluronic acid is a glycosaminoglycan made of repeating units of glucuronic acid and acetylglucosamine. Diglycidyl ether-mediated cross-linking of hyaluronic acid generates a high molecular weight relatively incompressible material that is resistant to rapid degradation. Injected cross-linked hyaluronic acid settles in pockets of loosely packed collagen fibrils, where, because of its biomechanical properties, it fills space and exerts internal pressure (Kablik et al. 2009). Enhancing structural support in the dermis by injection of cross-linked hyaluronic acid caused focal compression of the collagenous extracellular matrix resulting in fibroblasts acquiring a stretched morphology and forming more focal adhesions with adjacent extracellular matrix. These cellular alterations were accompanied by restoration of TGF- $\beta$ signaling and type I collagen production in fibroblasts (Wang et al. 2007; Quan et al. 2013). These results provide proof of principle that enhancing mechanical tension within the dermis of chronologically aged or photoaged skin effectively activates fibroblasts to achieve a more youthful state, which is clinically readily observable (Turlier et al. 2013). These results also provide further support for the concept that decline of fibroblast function, in chronologically aged and photoaging human skin, reflects the degraded properties of the dermal extracellular matrix microenvironment and is reversible.

\section{CONCLUDING REMARKS}

Chronic sun exposure causes photoaging, which can be viewed as an environmental damage superimposed on chronological aging. Chronologically aged and photoaged skin are clinically distinct, but share similar biochemical and cellular features. Chief among these common traits is accumulation of damage to the long-lasting extracellular matrix fibers of collagen and elastin. Expression of MMPs, which degrade proteins that comprise the dermal extracellular matrix, is elevated during natural aging and induced in response to UV irradiation. MMPmediated collagen fragmentation accumulates with the passage of time and repeated UV exposure. Fragmentation of collagen impairs the mechanical integrity of the dermis, thereby driving sustained reduction of collagenesis and, ultimately, loss of collagen matrix in aged and photoaged skin. Thus, age-related alterations of fibroblast functions, which deleteriously impact the health of human skin, largely reflect the degraded state of their dermal microenvironment. Indeed, increasing structural support within the dermis promotes a more youthful phenotype of fibroblasts in chronologically aged or photoaged skin.

\section{ACKNOWLEDGMENTS}

The authors acknowledge former and current investigators who have contributed to knowledge of skin aging. Citation of relevant literature 
could not be comprehensive and apologies are extended to those whose work could not be included in this review. Support was provided by grants AR059678 (L.R.), AG019364 (G.J.F.), and AG031452 (G.J.F.) from the National Institutes of Health.

\section{REFERENCES}

Agrawal A, Agrawal S, Cao JN, Su H, Osann K, Gupta S. 2007. Altered innate immune functioning of dendritic cells in elderly humans: A role of phosphoinositide 3-kinase-signaling pathway. J Immunol 178: 69126922.

Armulik A, Abramsson A, Betsholtz C. 2005. Endothelial/ pericyte interactions. Circ Res 97: 512-523.

Baadsgaard O, Lisby S, Wantzin GL, Wulf HC, Cooper KD. 1989. Rapid recovery of Langerhans cell alloreactivity, without induction of autoreactivity, after in vivo ultraviolet A, but not ultraviolet B exposure of human skin. $J$ Immunol 142: 4213-4218.

Barrandon Y, Green H. 1987. Three clonal types of keratinocyte with different capacities for multiplication. Proc Natl Acad Sci 84: 2302-2306.

Bennett MF, Robinson MK, Baron ED, Cooper KD. 2008. Skin immune systems and inflammation: Protector of the skin or promoter of aging? J Invest Dermatol Symp Proc 13: $15-19$.

Betsholtz C, Lindblom P, Gerhardt H. 2005. Role of pericytes in vascular morphogenesis. EXS: 115-125.

Bhushan M, Cumberbatch M, Dearman RJ, Kimber I, Griffiths CE. 2004. Exogenous interleukin-1 $\beta$ restores impaired Langerhans cell migration in aged skin. Br J Dermatol 150: 1217-1218.

Braverman IM, Fonferko E. 1982. Studies in cutaneous aging: I. The elastic fiber network. J Invest Dermatol 78: 434-443.

Brenneisen P, Wenk J, Klotz LO, Wlaschek M, Briviba K, Krieg T, Sies H, Scharffetter-Kochanek K. 1998. Central role of Ferrous/Ferric iron in the ultraviolet B irradiation-mediated signaling pathway leading to increased interstitial collagenase (matrix-degrading metalloprotease (MMP)-1) and stromelysin-1 (MMP-3) mRNA levels in cultured human dermal fibroblasts. J Biol Chem 273: 5279-5287.

Brooke RC, Newbold SA, Telfer NR, Griffiths CE. 2001. Discordance between facial wrinkling and the presence of basal cell carcinoma. Arch Dermatol 137: 751754.

Chen CS. 2008. Mechanotransduction-A field pulling together? J Cell Sci 121: 3285-3292.

Choi EH, Man MQ, Xu P, Xin S, Liu Z, Crumrine DA, Jiang YJ, Fluhr JW, Feingold KR, Elias PM, et al. 2007. Stratum corneum acidification is impaired in moderately aged human and murine skin. J Invest Dermatol 127: 2847 2856

Chumlea WC, Baumgartner RN. 1989. Status of anthropometry and body composition data in elderly subjects. Am J Clin Nutr 50: discussion 1231-1235.
Chung JH. 2003. Photoaging in Asians. Photodermatol Photoimmunol Photomed 19: 109-121.

Chung JH, Yano K, Lee MK, Youn CS, Seo JY, Kim KH, Cho KH, Eun HC, Detmar M. 2002. Differential effects of photoaging vs intrinsic aging on the vascularization of human skin. Arch Dermatol 138: 1437-1442.

Cueni LN, Detmar M. 2006. New insights into the molecular control of the lymphatic vascular system and its role in disease. J Invest Dermatol 126: 2167-2177.

Delvoye P, Wiliquet P, Levêque JL, Nusgens BV, Lapière CM. 1991. Measurement of mechanical forces generated by skin fibroblasts embedded in a three-dimensional collagen gel. J Invest Dermatol 97: 898-902.

Denu JM, Tanner KG. 1998. Specific and reversible inactivation of protein tyrosine phosphatases by hydrogen peroxide: Evidence for a sulfenic acid intermediate and implications for redox regulation. Biochemistry (Mosc) 37: 5633-5642.

Duncan MR, Frazier KS, Abramson S, Williams S, Klapper H, Huang X, Grotendorst GR. 1999. Connective tissue growth factor mediates transforming growth factor $\beta$ induced collagen synthesis: Down-regulation by cAMP. FASEB J 13: 1774-1786.

Du Nouy PL. 1916. Cicatrization of Wounds: III. The relation between the age of the patient, the area of the wound, and the index of cicatrization. J Exp Med 24: 461-470.

Eckes B, Zweers MC, Zhang ZG, Hallinger R, Mauch C, Aumailley M, Krieg T. 2006. Mechanical tension and integrin $\alpha 2 \beta 1$ regulate fibroblast functions. J Invest Dermatol Symp Proc 11: 66-72.

Elias PM, Goerke J, Friend DS. 1977. Mammalian epidermal barrier layer lipids: Composition and influence on structure. J Invest Dermatol 69: 535-546.

Elias PM, Williams ML, Crumrine D, Schmuth M. 2010. Ichthyoses: Clinical, biochemical, pathogenic and diagnostic assessment. Introduction. Curr Probl Dermatol 39: $1-29$.

Fisher GJ, Voorhees JJ. 1998. Molecular mechanisms of photoaging and its prevention by retinoic acid: Ultraviolet irradiation induces MAP kinase signal transduction cascades that induce Ap-1-regulated matrix metalloproteinases that degrade human skin in vivo. J Invest Dermatol Symp Proc 3: 61-68.

Fisher GJ, Datta SC, Talwar HS, Wang ZQ, Varani J, Kang S, Voorhees JJ. 1996. Molecular basis of sun-induced premature skin ageing and retinoid antagonism. Nature 379: 335-339.

Fisher GJ, Datta S, Wang Z, Li XY, Quan T, Chung JH, Kang S, Voorhees JJ. 2000. c-Jun-dependent inhibition of cutaneous procollagen transcription following ultraviolet irradiation is reversed by all-trans retinoic acid. J Clin Invest 106: 663-670.

Fisher GJ, Kang S, Varani J, Bata-Csorgo Z, Wan Y, Datta S, Voorhees JJ. 2002. Mechanisms of photoaging and chronological skin aging. Arch Dermatol 138: 1462-1470.

Fisher GJ, Quan T, Purohit T, Shao Y, Cho MK, He T, Varani J, Kang S, Voorhees JJ. 2009. Collagen fragmentation promotes oxidative stress and elevates matrix metalloproteinase- 1 in fibroblasts in aged human skin. Am J Pathol 174: $101-114$. 
Fraiture AL, Pierard-Franchimont C, Pierard GE. 1998. The cutaneous neurosensory axis and the neuro-immunocutaneous system. Rev Med Liege 53: 676-679.

Frederiksen L, Nielsen TL, Wraae K, Hagen C, Frystyk J, Flyvbjerg A, Brixen K, Andersen M. 2009. Subcutaneous rather than visceral adipose tissue is associated with adiponectin levels and insulin resistance in young men. $J$ Clin Endocrinol Metab 94: 4010-4015.

Fromy B, Sigaudo-Roussel D, Gaubert-Dahan ML, Rousseau P, Abraham P, Benzoni D, Berrut G, Saumet JL. 2010. Aging-associated sensory neuropathy alters pressure-induced vasodilation in humans. J Invest Dermatol 130: 849-855.

Gavi S, Feiner JJ, Melendez MM, Mynarcik DC, Gelato MC, McNurlan MA. 2007. Limb fat to trunk fat ratio in elderly persons is a strong determinant of insulin resistance and adiponectin levels. J Gerontol A Biol Sci Med Sci 62: 997 1001.

Gerstein AD, Phillips TJ, Rogers GS, Gilchrest BA. 1993. Wound healing and aging. Dermatol Clin 11: 749-757.

Giangreco A, Qin M, Pintar JE, Watt FM. 2008. Epidermal stem cells are retained in vivo throughout skin aging. Aging Cell 7: 250-259.

Giangreco A, Goldie SJ, Failla V, Saintigny G, Watt FM. 2010. Human skin aging is associated with reduced expression of the stem cell markers $\beta 1$ integrin and MCSP. J Invest Dermatol 130: 604-608.

Gilchrest BA, Blog FB, Szabo G. 1979. Effects of aging and chronic sun exposure on melanocytes in human skin. $J$ Invest Dermatol 73: 141-143.

Gosain A, DiPietro LA. 2004. Aging and wound healing. World J Surg 28: 321-326.

Grassi G, Seravalle G, Turri C, Bertinieri G, Dell'Oro R, Mancia G. 2003. Impairment of thermoregulatory control of skin sympathetic nerve traffic in the elderly. Circulation 108: $729-735$.

Gulcelik NE, Halil M, Ariogul S, Usman A. 2013. Adipocytokines and aging: Adiponectin and leptin. Minerva Endocrinol 38: 203-210.

Guo W, Pirtskhalava T, Tchkonia T, Xie W, Thomou T, Han J, Wang T, Wong S, Cartwright A, Hegardt FG, et al. 2007. Aging results in paradoxical susceptibility of fat cell progenitors to lipotoxicity. Am J Physiol Endocrinol Metab 292: E1041-E1051.

Halasz NA. 1968. Dehiscence of laparotomy wounds. Am J Surg 116: 210-214.

Hanson KM, Simon JD. 1998. Epidermal trans-urocanic acid and the UV-A-induced photoaging of the skin. Proc Natl Acad Sci 95: 10576-10578.

Harman D. 1992. Free radical theory of aging. Mutat Res 275: $257-266$.

Hawk JL. 1990. Photosensitivity in the elderly. Br J Dermatol 122: 29-36.

Helmbold P, Lautenschlager C, Marsch W, Nayak RC. 2006. Detection of a physiological juvenile phase and the central role of pericytes in human dermal microvascular aging. J Invest Dermatol 126: 1419-1421.

Herrlich P, Bohmer FD. 2000. Redox regulation of signal transduction in mammalian cells. Biochem Pharmacol 59: $35-41$.
Hirata A, Nomura T, Laakso I. 2012. Computational estimation of decline in sweating in the elderly from measured body temperatures and sweating for passive heat exposure. Physiol Meas 33: N51-N60.

Hodgson C. 1963. Senile lentigo. Arch Dermatol 87: 197207.

Holt DR, Kirk SJ, Regan MC, Hurson M, Lindblad WJ, Barbul A. 1992. Effect of age on wound healing in healthy human beings. Surgery 112: 293-297.

Hughes VA, Roubenoff R, Wood M, Frontera WR, Evans WJ, Fiatarone Singh MA. 2004. Anthropometric assessment of 10 -y changes in body composition in the elderly. Am J Clin Nutr 80: 475-482.

Inoue Y, Shibasaki M. 1996a. Regional differences in agerelated decrements of the cutaneous vascular and sweating responses to passive heating. Eur J Appl Physiol 74: $78-84$.

Inoue Y, Shibasaki M. 1996b. Regional differences in agerelated decrements of the cutaneous vascular and sweating responses to passive heating. Eur J Appl Physiol Occup Physiol 74: 78-84

Inoue Y, Shibasaki M, Ueda H, Ishizashi H. 1999. Mechanisms underlying the age-related decrement in the human sweating response. Eur J Appl Physiol 79: 121-126.

Jones PH, Watt FM. 1993. Separation of human epidermal stem cells from transit amplifying cells on the basis of differences in integrin function and expression. Cell 73: 713-724.

Kablik J, Monheit GD, Yu L, Chang G, Gershkovich J. 2009. Comparative physical properties of hyaluronic acid dermal fillers. Dermatol Surg 35: 302-312.

Kajiya K, Kunstfeld R, Detmar M, Chung JH. 2007. Reduction of lymphatic vessels in photodamaged human skin. J Dermatol Sci 47: 241-243.

Kelly RI, Pearse R, Bull RH, Leveque JL, de Rigal J, Mortimer PS. 1995. The effects of aging on the cutaneous microvasculature. J Am Acad Dermatol 33: 749-756.

Kim EJ, Kim YK, Kim JE, Kim S, Kim MK, Park CH, Chung JH. 2011. UV modulation of subcutaneous fat metabolism. J Invest Dermatol 131: 1720-1726.

Kligman AM. 1979. Perspectives and problems in cutaneous gerontology. J Invest Dermatol 73: 39-46.

Knebel A, Rahmsdorf HJ, Ullrich A, Herrlich P. 1996. Dephosphorylation of receptor tyrosine kinases as target of regulation by radiation, oxidants or alkylating agents. EMBO J 15: 5314-5325.

Kollias N, Sayre RM, Zeise L, Chedekel MR. 1991. Photoprotection by melanin. J Photochem Photobiol B 9: 135160.

Lau K, Paus R, Tiede S, Day P, Bayat A. 2009. Exploring the role of stem cells in cutaneous wound healing. Exp Dermatol 18: 921-933.

Lavker RM. 1995. Cutaneous aging: Chronologic versus photoaging. In Photodamage (ed. Gilchrest BA), pp. 123 135. Blackwell Science, Cambridge, MA.

Lavker RM, Zheng PS, Dong G. 1987. Aged skin: A study by light, transmission electron, and scanning electron microscopy. J Invest Dermatol 88: 44s-51s.

Lavker RM, Zheng PS, Dong G. 1989. Morphology of aged skin. Clin Geriatr Med 5: 53-67. 
Legat FJ, Wolf P. 2006. Photodamage to the cutaneous sensory nerves: Role in photoaging and carcinogenesis of the skin? Photochem Photobiol Sci 5: 170-176.

Legat FJ, Wolf P. 2009. Cutaneous sensory nerves: Mediators of phototherapeutic effects? Front Biosci 14: 4921-4931.

Legg J, Jensen UB, Broad S, Leigh I, Watt FM. 2003. Role of melanoma chondroitin sulphate proteoglycan in patterning stem cells in human interfollicular epidermis. Development 130: 6049-6063.

Luebberding S, Krueger N, Kerscher M. 2013. Age-related changes in skin barrier function-Quantitative evaluation of 150 female subjects. Int J Cosmet Sci 35: 183-190.

Mahbub S, Brubaker AL, Kovacs EJ. 2011. Aging of the innate immune system: An update. Curr Immunol Rev 7: $104-115$.

Man MQ, Xin SJ, Song SP, Cho SY, Zhang XJ, Tu CX, Feingold KR, Elias PM. 2009. Variation of skin surface $\mathrm{pH}$, sebum content and stratum corneum hydration with age and gender in a large Chinese population. Skin Pharmacol Physiol 22: 190-199.

Marples MJ. 1965. The ecology of the human skin. Charles C. Thomas, Springfield, IL.

Martin HL, Loomis JL, Kenney WL. 1995. Maximal skin vascular conductance in subjects aged 5-85 yr. J Appl Physiol 79: 297-301.

Massagué J. 2012. TGF $\beta$ signalling in context. Nat Rev Mol Cell Biol 13: 616-630.

Mauch C, Hatamochi A, Scharffetter K, Krieg T. 1988. Regulation of collagen synthesis in fibroblasts within a threedimensional collagen gel. Exp Cell Res 178: 493-503.

Mendoza CB Jr, Postlethwait RW, Johnson WD. 1970. Veterans Administration cooperative study of surgery for duodenal ulcer: II. Incidence of wound disruption following operation. Arch Surg 101: 396-398.

Meng FG, Zhang ZY. 2013. Redox regulation of protein tyrosine phosphatase activity by hydroxyl radical. Biochim Biophys Acta 1834: 464-469.

Meredith P, Sarna T. 2006. The physical and chemical properties of eumelanin. Pigment Cell Res 19: 572-594.

Mine S, Fortunel NO, Pageon H, Asselineau D. 2008. Aging alters functionally human dermal papillary fibroblasts but not reticular fibroblasts: A new view of skin morphogenesis and aging. PLoS ONE 3: e4066.

Montagna W. 1977. Morphology of cutaneous sensory receptors. J Invest Dermatol 69: 4-7.

Montagna W, Carlisle K. 1979. Structural changes in aging human skin. J Invest Dermatol 73: 47-53.

Montagna W, Carlisle K. 1991. The architecture of black and white facial skin. J Am Acad Dermatol 24: 929-937.

Namer B. 2010. Age related changes in human C-fiber function. Neurosci Lett 470: 185-187.

Ongrádi J, Stercz B, Kövesdi V, Vértes L. 2009. Immunosenescence and vaccination of the elderly: I. Age-related immune impairment. Acta Microbiol Immunol Hung 56: 199-210.

Ortonne JP. 1990. Pigmentary changes of the ageing skin. $\mathrm{Br}$ J Dermatol 122: 21-28.

Panoutsopoulou IG, Wendelschafer-Crabb G, Hodges JS, Kennedy WR. 2009. Skin blister and skin biopsy to quan- tify epidermal nerves: A comparative study. Neurology 72: 1205-1210.

Quan T, He T, Kang S, Voorhees JJ, Fisher GJ. 2002. Connective tissue growth factor: Expression in human skin in vivo and inhibition by ultraviolet irradiation. J Invest Dermatol 118: 402-408.

Quan T, He T, Kang S, Voorhees JJ, Fisher GJ. 2004. Solar ultraviolet irradiation reduces collagen in photoaged human skin by blocking transforming growth factor- $\beta$ type II receptor/Smad signaling. Am J Pathol 165: 741-751.

Quan T, He T, Voorhees JJ, Fisher GJ. 2005. Ultraviolet irradiation induces Smad7 via induction of transcription factor AP-1 in human skin fibroblasts. J Biol Chem 280: 8079-8085.

Quan T, Wang F, Shao Y, Rittié L, Xia W, Orringer JS, Voorhees JJ, Fisher GJ. 2013. Enhancing structural support of the dermal microenvironment activates fibroblasts, endothelial cells, and keratinocytes in aged human skin in vivo. J Invest Dermatol 133: 658-667.

Reinisch CM, Tschachler E. 2012. The dimensions and characteristics of the subepidermal nerve plexus in human skin-Terminal Schwann cells constitute a substantial cell population within the superficial dermis. J Dermatol Sci 65: $162-169$.

Rittié L, Fisher GJ. 2002. UV-light-induced signal cascades and skin aging. Ageing Res Rev 1: 705-720.

Rittié L, Berton A, Monboisse JC, Hornebeck W, Gillery P. 1999. Decreased contraction of glycated collagen lattices coincides with impaired matrix metalloproteinase production. Biochem Biophys Res Commun 264: 488-492.

Rittié L, Stoll SW, Kang S, Voorhees JJ, Fisher GJ. 2009. Hedgehog signaling maintains hair follicle stem cell phenotype in young and aged human skin. Aging Cell 8: $738-$ 751.

Rittié L, Sachs DL, Orringer JS, Voorhees JJ, Fisher GJ. 2013. Eccrine sweat glands are major contributors to reepithelialization of human wounds. Am J Pathol 182: 163-171.

Rohrich RJ, Pessa JE. 2007. The fat compartments of the face: Anatomy and clinical implications for cosmetic surgery. Plast Reconstr Surg 119: 2219-2227; discussion 2228-2231.

Rohrich RJ, Pessa JE. 2008. The retaining system of the face: Histologic evaluation of the septal boundaries of the subcutaneous fat compartments. Plast Reconstr Surg 121: 1804-1809.

Rosette C, Karin M. 1996. Ultraviolet light and osmotic stress: Activation of the JNK cascade through multiple growth factor and cytokine receptors. Science 274: $1194-$ 1197.

Ross R, Leger L, Morris D, de Guise J, Guardo R. 1992. Quantification of adipose tissue by MRI: Relationship with anthropometric variables. J Appl Physiol 72: 787795.

Ross R, Shaw KD, Martel Y, de Guise J, Avruch L. 1993. Adipose tissue distribution measured by magnetic resonance imaging in obese women. Am J Clin Nutr 57: 470475.

Sandblom P. 1953. Determination of the tensile strength of the healing wound as a clinical test. J Inter Chir 13: 1-4. 
Sato K, Dobson RL. 1970. Regional and individual variations in the function of the human eccrine sweat gland. J Invest Dermatol 54: 443-449.

Schneider EL. 1979. Aging and cultured human skin fibroblasts. J Invest Dermatol 73: 15-18.

Sepe A, Tchkonia T, Thomou T, Zamboni M, Kirkland JL. 2011. Aging and regional differences in fat cell progenitors-A mini-review. Gerontology 57: 66-75.

Shaw AC, Joshi S, Greenwood H, Panda A, Lord JM. 2010 Aging of the innate immune system. Curr Opin Immunol 22: $507-513$.

Shlivko IL, Petrova GA, Zor'kina MV, Tchekalkina OE, Firsova MS, Ellinsky DO, Agrba PD, Kamensky VA, Donchenko EV. 2013. Complex assessment of age-specific morphofunctional features of skin of different anatomic localizations. Skin Res Technol 19: e85-e92.

Sklar LR, Almutawa F, Lim HW, Hamzavi I. 2013. Effects of ultraviolet radiation, visible light, and infrared radiation on erythema and pigmentation: A review. Photochem Photobiol Sci 12: 54-64.

Snell RS, Bischitz PG. 1963. The melanocytes and melanin in human abdominal wall skin: A survey made at different ages in both sexes and during pregnancy. J Anat 97: 361-376.

Stern MM, Bickenbach JR. 2007. Epidermal stem cells are resistant to cellular aging. Aging Cell 6: 439-452.

Szabo G. 1967. The regional anatomy of the human integument with special reference to the distribution of hair follicles, sweat glands and melanocytes. Phil Trans R Soc Lond B 252: 447-485.

Takahashi I, Ohmoto E, Aoyama S, Takizawa M, Oda Y Nonaka K, Nakada H, Yorimitsu S, Kimura I. 1985. Monocyte chemiluminescence and macrophage precursors in the aged. Acta Med Okayama 39: 447-451.

Talwar HS, Griffiths CE, Fisher GJ, Hamilton TA, Voorhees JJ. 1995. Reduced type I and type III procollagens in photodamaged adult human skin. J Invest Dermatol 105: $285-290$.

Thomas EL, Saeed N, Hainal JV, Brynes A, Goldstone AP, Frost G, Bell JD. 1998. Magnetic resonance imaging of total body fat. J Appl Physiol 85: 1778-1785.

Tonks NK. 2006. Protein tyrosine phosphatases: From genes, to function, to disease. Nat Rev Mol Cell Biol 7: 833-846.

Toyoda M, Hara M, Bhawan J. 1996. Epidermal innervation correlates with severity of photodamage. A quantitative ultrastructural study. Exp Dermatol 5: 260-266.

Toyoda M, Nakamura M, Nakada K, Nakagawa H, Morohashi M. 2005. Characteristic alterations of cutaneous neurogenic factors in photoaged skin. Br J Dermatol 153: $13-22$.

Turlier V, Delalleau A, Casas C, Rouquier A, Bianchi P, Alvarez S, Josse G, Briant A, Dahan S, Saint-Martory C, et al. 2013. Association between collagen production and mechanical stretching in dermal extracellular matrix:
In vivo effect of cross-linked hyaluronic acid filler. A randomised, placebo-controlled study. J Dermatol Sci 69: $187-194$.

Uitto J. 1986. Connective tissue biochemistry of the aging dermis. Age-related alterations in collagen and elastin. Dermatol Clin 4: 433-446.

Varani J, Warner RL, Gharaee-Kermani M, Phan SH, Kang S, Chung JH, Wang ZQ, Datta SC, Fisher GJ, Voorhees JJ. 2000. Vitamin A antagonizes decreased cell growth and elevated collagen-degrading matrix metalloproteinases and stimulates collagen accumulation in naturally aged human skin. J Invest Dermatol 114: 480-486.

Varani J, Spearman D, Perone P, Fligiel SE, Datta SC, Wang ZQ, Shao Y, Kang S, Fisher GJ, Voorhees JJ. 2001. Inhibition of type I procollagen synthesis by damaged collagen in photoaged skin and by collagenase-degraded collagen in vitro. Am J Pathol 158: 931-942.

Varani J, Perone P, Fligiel SE, Fisher GJ, Voorhees JJ. 2002. Inhibition of type I procollagen production in photodamage: Correlation between presence of high molecular weight collagen fragments and reduced procollagen synthesis. J Invest Dermatol 119: 122-129.

Varani J, Dame MK, Rittié L, Fligiel SE, Kang S, Fisher GJ, Voorhees JJ. 2006. Decreased collagen production in chronologically aged skin: Roles of age-dependent alteration in fibroblast function and defective mechanical stimulation. Am J Pathol 168: 1861-1868.

Vukmanovic-Stejic M, Rustin MH, Nikolich-Zugich J, Akbar AN. 2011. Immune responses in the skin in old age. Curr Opin Immunol 23: 525-531.

Wang F, Garza LA, Kang S, Varani J, Orringer JS, Fisher GJ, Voorhees JJ. 2007. In vivo stimulation of de novo collagen production caused by cross-linked hyaluronic acid dermal filler injections in photodamaged human skin. Arch Dermatol 143: 155-163.

Wang F, Garza LA, Cho S, Kafi R, Hammerberg C, Quan T, Hamilton T, Mayes M, Ratanatharathorn V, Voorhees JJ, et al. 2008. Effect of increased pigmentation on the antifibrotic response of human skin to UV-A1 phototherapy. Arch Dermatol 144: 851-858.

Weller R, Pattullo S, Smith L, Golden M, Ormerod A, Benjamin N. 1996. Nitric oxide is generated on the skin surface by reduction of sweat nitrate. J Invest Dermatol 107: 327-331.

Xu D, Rovira II, Finkel T. 2002. Oxidants painting the cysteine chapel: Redox regulation of PTPs. Dev Cell 2: 251-252.

Xu Y, Tan LJ, Grachtchouk V, Voorhees JJ, Fisher GJ. 2005. Receptor-type protein-tyrosine phosphatase-к regulates epidermal growth factor receptor function. J Biol Chem 280: 42694-42700.

Xu Y, Shao Y, Voorhees JJ, Fisher GJ. 2006. Oxidative inhibition of receptor-type protein-tyrosine phosphatase $\kappa$ by ultraviolet irradiation activates epidermal growth factor receptor in human keratinocytes. J Biol Chem 281: 27389-27397. 


\section{$\&_{\mathrm{CSH}}^{\infty} \&$ Cold Spring Harbor

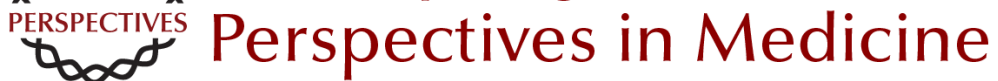

\section{Natural and Sun-Induced Aging of Human Skin}

Laure Rittié and Gary J. Fisher

Cold Spring Harb Perspect Med 2015; doi: 10.1101/cshperspect.a015370

Subject Collection The Skin and Its Diseases

Melanoma: Clinical Features and Genomic Insights

Elena B. Hawryluk and Hensin Tsao

Wound Healing and Skin Regeneration

Makoto Takeo, Wendy Lee and Mayumi Ito

The Dermal Papilla: An Instructive Niche for

Epithelial Stem and Progenitor Cells in

Development and Regeneration of the Hair Follicle Bruce A. Morgan

Immunology and Skin in Health and Disease Jillian M. Richmond and John E. Harris

Desmosomes: Regulators of Cellular Signaling and Adhesion in Epidermal Health and Disease Jodi L. Johnson, Nicole A. Najor and Kathleen J. Green

Markers of Epidermal Stem Cell Subpopulations in Adult Mammalian Skin Kai Kretzschmar and Fiona M. Watt

Psoriasis Paola Di Meglio, Federica Villanova and Frank O. Nestle

Cell Therapy in Dermatology Gabriela Petrof, Alya Abdul-Wahab and John A. McGrath
Modeling Cutaneous Squamous Carcinoma

Development in the Mouse

Phillips Y. Huang and Allan Balmain

Natural and Sun-Induced Aging of Human Skin Laure Rittié and Gary J. Fisher

Advanced Treatment for Basal Cell Carcinomas Scott X. Atwood, Ramon J. Whitson and Anthony E. Oro

Epidermal Polarity Genes in Health and Disease Frederik Tellkamp, Susanne Vorhagen and Carien M. Niessen

Induced Pluripotent Stem Cells in Dermatology:

Potentials, Advances, and Limitations Ganna Bilousova and Dennis R. Roop

The Genetics of Human Skin Disease Gina M. DeStefano and Angela M. Christiano

p53/p63/p73 in the Epidermis in Health and Disease

Vladimir A. Botchkarev and Elsa R. Flores

Diversification and Specialization of Touch

Receptors in Skin

David M. Owens and Ellen A. Lumpkin

For additional articles in this collection, see http://perspectivesinmedicine.cshlp.org/cgi/collection/ 